\title{
The hedgification of maizescapes? Scalability and multifunctionality of Jatropha curcas hedges in a mixed farming landscape in Zambia
}

\author{
$\underline{\text { Dan van der Horst }}^{1}$, Saskia Vermevlen $^{2}$ and Elias Kuntashula ${ }^{3}$
}

\begin{abstract}
We argue that reading the local agricultural landscape is a prerequisite to understanding the plausible local impacts of external drivers for change, such as the introduction of new crops and technologies. Initially driven by a desire to understand the potential for small-scale farmers to produce jatropha biodiesel in a sustainable way, we started to examine how farmers related to trees in different parts of the agricultural landscape. This provided us with insights into small-scale processes of land enclosure and conversion, which indicate that agricultural intensification is taking place. We learned that although the landscape could in theory accommodate a lot of jatropha hedges around existing (maize dominated) arable land, farmers were only creating hedges around new fields, carved out in the grazing commons. Already well established within the settlement, jatropha can produce a range of different ecosystem services. However, our case study suggests that scalability is problematic: cultural ecosystem services can be provided at very limited levels of production; supporting ecosystem services require a certain scaling up of production; and provisioning ecosystem services, like biofuels, would require production to be increased well beyond any synergies with ongoing tree plantings or land conversion processes.
\end{abstract}

Key Words: Africa; agricultural intensification; biofuels; live fence; marginal land

\section{INTRODUCTION}

While studying the adoption by small-scale farmers of Jatropha curcas trees as a new and potentially 'propoor' cash crop (van der Horst et al. 2013, Kuntashula et al. 2014; Vermeylen and van der Horst, unpublished manuscript), we started to ask ourselves questions about the agricultural landscapes through which we moved, and the extent to which the place and fate of trees in rural villages and agricultural landscapes could be read as material indicators of particular processes of agrarian change and intensification. Over the course of several field seasons and in our search for literature when we were back at our desks, we felt increasingly that this topic area has been under researched. Here, we explore observed patterns and discuss plausible processes. Although we report empirics from one particular landscape, there is a wider relevance to the questions we ask about African agricultural landscapes and the social-ecological processes that shape them. Without understanding the landscape, we cannot truly grasp the potential impacts from exogenous developments. We framed our observations in two complementary ways: (1) the role of trees in the agricultural landscape, and (2) the ecosystem services (ES) consequences of increased tree plantings. Informed by our fieldwork observations, we focused especially on hedges.

Specific landscapes emerged as a result of human actions to enhance the provision of certain ecosystem services to the detriment of others. These actions in turn are informed by an often inseparable mixture of ecology, technology, and culture. Consisting of trees or bushes grown in unnatural density and linearity, hedges and live fences can be associated with relative social-ecological stability. Without sufficient socioeconomic stability farmers would not invest in the creation of hedges and once established, hedges are likely to survive in the landscape for decades, thus providing some ecological stability. Hedges can be found in many cultural landscapes (Budowski and Russo 1993, Stone 1994, Choudhury et al. 2005). Many long-established agricultural practices are characterized by multifunctionality, and hedges were often planted in such a manner that they provided multiple ecosystem services, such as wind breaks, prevention of soil erosion, keeping grazing animals away from agricultural crops, provision of food, fodder, or construction materials. The cultural significance of hedges has also been widely recognized (Oreszczyn and Lane 2000, Fukamachi et al. 2011). Research has shown that these hedges can also be important for biodiversity, aiding the survival of forest edge species in largely agricultural landscapes in which much of the original tree cover has been removed (Hinsley and Bellamy 2000, Holland and Fahrig 2000, Usieta et al. 2013).

Most existing research on agricultural hedges focused on developed countries, in which mechanization has led to the removal and decline of traditional hedges. Choudhury et al. (2004) noted that local fencing practices in developing countries have received little attention to date. After looking for new literature ourselves, we must report that this observation still stands a decade later. On the other hand, there have been many reports on new efforts, i.e. separate from local traditions, to promote agroforestry as a form of (more) sustainable agriculture (Kabwe 2010, Kelso and Jacobson 2011) and linear forms of tree planting have been encouraged as efforts of restoration ecology, e.g. to reduce soil erosion, provide wind breaks or fire breaks, and buffer streams from run-off from agricultural land (Levasseur et al. 2004, Zahawi 2005, Williams 2011). In other words, regulating services often provide the key rationale for NGOs or government agencies that are trying to convince small-scale farmers to adopt tree planting. Although the potential ecosystem services of such fences are frequently mentioned by academics and development professionals, it is often not clear what the drivers and barriers are for the local farmers themselves to establish live fences in agricultural landscapes, especially if this practice is not yet locally embedded and if external support is absent. Managing risk is a key concern of farmers because they have to deal with various uncontrollable factors, e.g., climate, market prices, while aiming to pass the farm on to the next generation. Family values, regional cultural traditions, observed parental practices, and personal heuristics all play a role in informing the farmer's decisions. In developing countries, formal modern science is hardly accessible for the average farmer, and these forms of local knowledge and experience are more important still. Understanding indigenous 
farming systems and local farming practices is therefore a prerequisite for the successful promotion of any farming innovation. After all, some farmers stand to benefit more from the adoption than others, some can afford to take more risk than others, and some have more knowledge and experience relevant for the adoption. Indeed, dismissal of local farmer knowledge and insistence on a blanket approach have been key reasons for the poor adoption rates of many agroforestry schemes in developing countries (Kabwe 2010).

We examined a small-scale mixed farming system in eastern Zambia in which farmers are accustomed to planting trees in the yard because this is an established local practice, but their fields were almost devoid of trees. We aim (1) to identify the existing tree planting and management practices within the agricultural landscape, (2) to understand how planted trees are used and what ecosystem services they provide, and (3) to examine the trade-offs in ecosystem service delivery inherent in the scaling up of tree planting practices. In addressing these aims, we focused mainly on hedge planting, a practice that is widely found in mixed farming systems in Zambia, where we did our fieldwork.

Species, such as Jatropha curcas, henceforth referred to as jatropha, milk bush, Euphorbia tirucalli, and yellow oleander, Thevetia peruviana, are widely used as hedges in Zambia. What the three species have in common is that they are toxic and therefore not browsed by livestock. However, we focused on jatropha for two reasons: as a plant it is used in more inventive and diverse ways than the other two plants, and its seeds have gained commercial value. Unlike the other species, its wider adoption has the potential to provide more direct income to farmers. Furthermore, as a candidate biofuel crop, jatropha has been very widely promoted and studied in recent years (Openshaw 2000, Achten et al. 2007, Jongschaap et al. 2007, ArizaMontobbio et al. 2010, Boerstler 2010, Hunsberger 2010, Mponela et al. 2011). Although it has largely failed as a cash crop grown in the field, various authors have argued that it should be promoted as a hedge, e.g., along the field margins, thus avoiding the displacement of food crops (Henning 1996, Dyer et al. 2012). Jatropha thus represents a case of external efforts to scale up the planting of a particular nonfood tree within an existing agricultural landscape, with claims that it can be done in a way that balances different ecosystem services. Although the food or fuel debate and the discussions about the definition and availability of 'marginal' land continue, and the gap between general claims about the potential production of sustainable biofuels and evidence of operational propoor biofuel systems remains as big as ever (van der Horst and Vermeylen 2011). To our knowledge, the potential of a particular agricultural landscape to actually accommodate more jatropha hedges, and the local trade-offs and synergies arising from this 'hedgification' have not been researched. We thus contribute both to the debate on sustainable biofuels and the debate on the role of tree plantings in the intensification of small-holder agriculture in Africa.

\section{METHODOLOGY}

At the start of the project, which informs this paper, we visited different parts of Zambia to obtain information about the villagers' use of jatropha and about the efforts to adopt this tree as a new cash crop. Most fieldwork was concentrated in the Eastern Province in Zambia, in which we found jatropha to be a widespread village tree and in which two different foreign companies, Oval and D1, had tried (unsuccessfully) to develop outgrowers schemes among small-scale farmers to stimulate the production of jatropha seeds for the biofuels market.

As part of the project, a survey of 249 farmers took place in 4 different districts of the Eastern Province (Fig. 1) to develop a better understanding of the types of farmers who engaged in efforts to grow jatropha and to collect the seeds from existing bushes (reported in full in Kuntashula et al. 2014). We drew especially on more in-depth fieldwork in the Nyimba district and especially in Sikwenda, a village of about 100 households where D1 had been collecting jatropha seeds in the past. We chose this village because of the abundance of existing jatropha trees within the village. We spent multiple days in the village on six different occasions. We interviewed farmers in their yards and undertook village walks with key informants. Focus group discussions took place with members of the local farming cooperative, with people involved in jatropha soap making, with women farmers, and with the oldest members of the village. During our last visit, we held an open village meeting to convey our findings to date and verify that our reading of the agricultural landscape and tree planting practices had been accurate.

Fig. 1. Location of Zambia's Eastern Province, which borders on Mozambique to the south. Most of our fieldwork took place in the Nyimba district (bottom left).

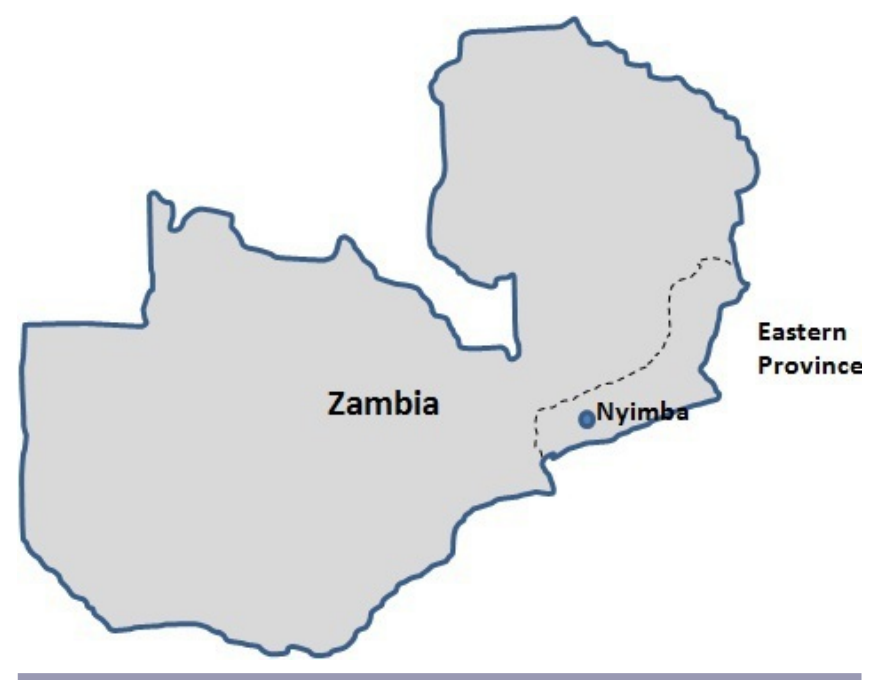

We also gained many insights through ethnography, participant observation, and informal exchanges during the many unplanned hours in the field, as we waited for lunch to be cooked, visited MSc students, walked through the village looking for a key informant, stopped in neighboring villages to ask for directions, made courtesy visits to local dignitaries, talked to people whom we gave a ride to into town, or moved through the jatropha bushes with some village assistants to find suitable sites to collect soil samples.

Interviews and observations helped us to identify the existing local uses of tree planting and the ecosystem services provided by these trees (aim 2). In addition, we used satellite imagery, i.e., SPOT 
images available on Google Earth, to better understand the spatial characteristics of the local villages and farming systems and to identify existing hedges in the landscape (aim 1). Focus group discussions played a key part in understanding the perceptions and trade-offs related to the scaling up of tree planting practices (aim 3). Last but not least, our work benefitted from the local knowledge and fieldwork experience of our Zambian colleagues, because for example, Kuntashula has carried out research with farmers in the Eastern Province for more than a decade.

\section{Case study area}

The Eastern Province is characterized by a flat to gently undulating landscape with altitudes ranging from 900 to $1200 \mathrm{~m}$ above sea level. The single rainy season $(1000 \mathrm{~mm} / \mathrm{y})$ lasts from November/December to March/April. Land tenure arrangements are governed by traditional authorities, i.e., chiefs and village heads. Population density ranges from 25 to 40 persons $\mathrm{km}^{2}$. About half the farmers have ox drawn ploughs, which allows them to cultivate at least twice as much land as those who work the land with the hoe. Maize is the most important crop in the area accounting for about $60 \%$ to $80 \%$ of total cultivated area (Franzel et al. 2002). Most farmers have some pigs and goats, which are allowed to roam around the village, and the better-off farmers also have some cows, which are herded by small boys during the day and locked up in the kraal at night.

\section{RESULTS}

\section{Landscape units in relation to tree management and the use of hedges}

We asked farmers in Sikwenda what trees or bushes they planted and where and what fencing methods they deployed and for what purpose. Apart from a few farmers in another village closer to town who had small banana plantations, the villagers did not know anyone who planted trees on arable land. To the contrary, they usually cut down trees, sparing only baobab and mango trees, both of which provide edible fruit. Some small trees could be left undisturbed at the boundary between their land and that of their neighbor, but any seedlings they found in the field were deliberately removed during weeding. Again, they made an exception for mango trees. Although they did not actively plant any mango trees in the field, they would spare any seedlings they came across. Indeed mangos were about the only mature trees that we saw standing in the middle of maize fields. The popularity of mango fruit lies partly in the time of its availability, i.e., in the early rainy season when the new food crops are not yet ripe and the old food stock is heavily depleted. As an abundant fruit in the hungry season, mango is taken to the field to eat during weeding and it thus becomes widely dispersed.

In addition to growing maize on their main fields during the wet season, some households had gardens in the dambos wetlands in the valley, where soil moisture was sufficient for growing vegetables in the dry season. This area was also popular for grazing and all vegetable gardens were fenced off with dead wood. More recently, some famers have planted agave fences instead.

The only tree planting that all villagers were familiar with, took place in their own yard. A broad range of different trees may be planted there, with shade and amenity being most frequently mentioned as motivation for tree planting. An individual homestead consists of one or two straw thatched houses and some smaller structures, i.e., grain store, bathroom, long-drop toilet, and chicken coop, and one or two trees for shade. The ground around these trees and structures is barren because the yard is swept meticulously clean every day. Bushes are often planted at the edge of the yard. In between the living spaces of individual households, we saw mature trees, open spaces where tall grasses grew during the wet season, the occasional cattle kraal or vegetable garden, holes in the ground where soil has been dug up to provide building material for the adobe walls of new homes and which were sometimes being used as rubbish dumps, and abandoned homesteads of people who had died after their children had already left home to set up their own households. Young families settled at the village edge where they could carve out their yard by clearing the bush, which was part of the common grazing land.

The common grazing land itself was relatively extensive, up to 1.5 $\mathrm{km}$ in width. Villagers simply referred to it as 'bush,' a zone delineated through local bylaw as common land for grazing, firewood collection, etc. Trees are browsed, cut, or coppiced here, not planted. Repeated visits to Sikwenda and other villages, made us realize that this zone was slowly shrinking because both the village and the fields were expanding over time. This was confirmed at a focus group meeting at which we were told that in the past, the villagers of Sikwenda had many more heads of cattle but that they never fully recovered from an outbreak of the livestock disease east coast fever in the 1990s. The village head had agreed to any request to clear the bush and convert it to yards and private gardens, stipulating only that it was the responsibility of the garden owners to construct fences to keep the cattle out of their garden. This is different from designated arable land, in which any crop damage caused by cattle must be reimbursed by the owner of the cattle.

In short, we identified four general landscape units with regard to the planting and management of trees (see Fig. 2). On high ground there is the village where many different trees may be planted and live fences may be built; then the (bushy) grazing commons on the (somewhat) steeper upper slopes where normally no tree planting would take place, unless it was being converted to a field or garden, which might require a live fence; then the fields of arable land on the lower slopes with no live fences and where trees were actively removed with the exception of mangos; and finally, the wet dambos on the valley floor where dead wood fences were the norm, occasionally substituted by agave.

\section{Jatropha in the village: uses and ecosystem services}

We saw jatropha in every village we visited in the Nyimba and Petauke districts. The Nsenga people living in this area call it "monokunda." Mono is a local name for castor beans, which are indeed related to jatropha. The Kunda people live in the Luangwa Valley, which drains into the Zambezi on the border with Mozambique. This points to the role of local trade and exchange networks through which new crops spread across Africa and is consistent with the plausible introduction of jatropha by Portuguese traders in the lower Zambezi.

During village walks, farmers showed us the various locally rooted uses of jatropha (see Fig. 3) and from our observations and discussions it became clear that the villages must be a particularly 
Fig. 2. Example of a typical village in the Eastern Province (SPOT image, taken in the dry season). On higher ground, there is a settlement with thatched grass huts and some mature trees (blue outline) surrounded by common grazing land with bushes (dotted green line) that gives way to open fields of arable land, interrupted only by some individual mango trees, and in the dambo wetland there are vegetable gardens (red outline). Outlined in black is the ubiquitous football field providing a sense of scale; $50 \times 100 \mathrm{~m}$.

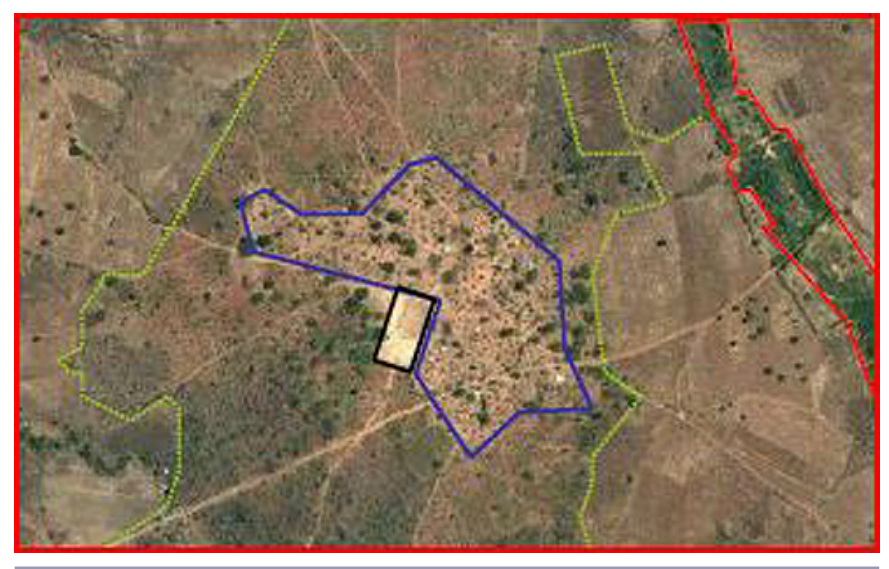

Fig. 3. Established village uses of jatropha (clockwise from top left): as live posts holding the straw mats (walls) of a bathroom; as part of a cattle kraal (picture taken from the inside); as a single shade tree in the yard (an ox cart parked underneath); and as a hedge around the yard.
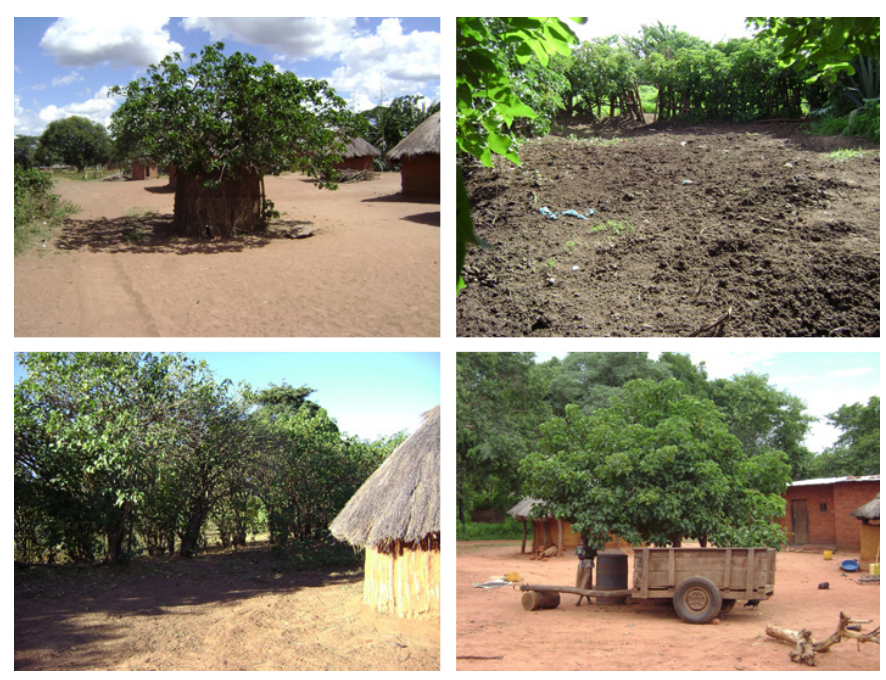

good ecological niche for jatropha. It benefits from nutrients, i.e., livestock droppings, and water, i.e., from the bathroom, protection against potentially harmful insects, especially termites, which are controlled by chickens, bush fires, and competition with other weeds, which are eaten by village livestock. Although a few of the seeds have been used for medicine and lighting, jatropha's main purpose, prior to the biofuel hype, seemed to have been nonconsumptive. When asked why they planted it, the most common answer was that it had 'nice flowers', but shade, wind protection, privacy, and some control of animal movement were also repeatedly mentioned. It was not normally grown in the field, but stimulated by biofuel companies, some farmers in the district had tried growing it in the field. However, they all found that it died without fertilizer, regular weeding, and protection against fire.

We observed several types of livestock-proof fences: sturdy logs for cattle kraals only, dead wood, agave hedges only seen around some vegetable plots on the edge of dambo wetlands, and jatropha fences on well drained sandy soils. Some fences were mixed, including dead wood with agave, dead wood with jatropha, logs with jatropha, straw mats with jatropha, and jatropha with cactus. The latter being laid down on the ground to discourage even the smallest pigs from wriggling through the jatropha fence and into the vegetable garden. We did not see any metal wire in the village. When we asked about it, we were told that it was very expensive. On the edge of towns and along main roads, we saw other hedges around houses rather than gardens, mainly milk bush and yellow oleander. In a focus group discussion, farmers said that they preferred jatropha to milk bush around the yard because the sap of the latter is a much stronger irritant, making it hard to cut it back.

In Sikwenda, we noted that jatropha was the most common bush or tree in the village. It was growing in the spaces between the individual households. Sometimes we could still detect the original shape of the planting, i.e., linear as a hedge, circular as a bathroom, but often we just saw clumps/groves of mature jatropha bushes. We observed how jatropha was spreading, i.e., falling down from the outer reaches of the branches, seeds germinated in a circle around the mature tree, and over time a single jatropha tree would become a jatropha grove.

In discussions about what it was like to live among jatropha bushes, to manage them, i.e., pruning, or harvest the seeds to sell to biofuel companies, farmers were quick to point out a number of risks. The trees would encroach around the yard, and people were afraid of snakes hiding in or under the trees. Wasps very often built their nests there and the bushes were a hiding place for mosquitoes in the rainy season. The seeds were sometimes digested by infants, making them very ill. Moving through the bushes to harvest the seeds inevitably meant that some leaves were broken off, exposing people to the sap of the plant, which stings a little on the skin and leaves indelible stains on clothes.

At the final focus group discussion, we raised the idea of planting a lot more jatropha. This was a 'real world' dilemma for farmers because they had been visited by biofuel company representatives who had tried to win them over to do just that. Sikwenda farmers said that labor was their key concern. If a household was big enough, then the labor availability for harvesting jatropha seeds was not seen as a problem. This is because harvesting, usually carried out by women and children, can be done at any time during the dry season because the seeds are lying on the ground untouched. Planting seedlings or saplings was also not seen as problematic because it is a one-time activity, which can take place at any time of the year. The real labor costs lie in weeding during 
the wet season and the creation of firebreaks at the onset of the dry season. Without weeding in the first two years, jatropha will not become established. Fire is ubiquitous in the dry season, lit by local people to hunt for small game, clear the land for replanting, encourage the growth of new grass, or in the case of early fire, protect their land against stronger fires later in the dry season. It is not only the amount of labor that is a problem, but also the timing. A jatropha sapling needs weeding at the same time that the maize field, the staple food, needs weeding, whereas the creation of fire breaks coincides with the maize harvesting time. These are the busiest times in the agricultural cycle. In the more densely populated parts of the Eastern Province, some surveyed farmers said that they did not have enough land to plant jatropha. However in Sikwenda and most other places, labor seemed to be the main problem. Every single farmer we spoke to saw their maize crop as their number one priority and allocated their labor accordingly. Household labor is a fickle resource, easily affected by family dynamics, disease, opportunities for external income generation, and rural-urban migration. We observed some maize fields, in which the crop was overgrown with weeds, a sign of unanticipated household labor shortage at the crucial time for weeding. Food security is at the forefront of the farmer's mind and growing maize generally wins out against any cash crop, and especially against a low value crop like jatropha. Moreover, the authorities' consistent involvement in stimulating maize production and in buying maize from farmers at regulated prices has ensured that maize is both a food and a cash crop, thus effectively encouraging farmers to pursue a maize only strategy. Jokingly referred to as the 'Ministry of Maize' by one of our NGO partners, the Ministry of Agriculture has thus played an influential role in shaping the maize-dominated agricultural landscape in the Eastern Province.

\section{DISCUSSION}

\section{Relevance of existing literature}

We cannot compare our findings about hedges with the literature because we found no other studies on the expansion of hedges in contemporary small-scale agricultural landscapes. We can however try to relate our findings to theory. We found that the construction of hedges in the landscape is increasing, as the bush between the village and the field is enclosed by new yards and new fields and as the open spaces in the village are enclosed by new gardens. Given that these microenclosures are clearly acts of agricultural intensification, and that the hedges are novel in structure and location, we draw on Boserup's (1965) induced innovation to make theoretical sense of the findings. Population growth leads to agricultural innovations that allow a growing rural population to sustain itself with the same amount of land but with more labor input. The adoption and diverse application of live fences is a technological innovation, which creates a spatial division in the production and allocation of ecosystem services. Live fences are a form of ecology-as-technology, or in other words both human made and natural capital, because the plants would not grow by themselves in such a manner, and yet they provide additional ecosystem services by and of themselves. Despite the role of some external factors, like the new hand pumps in the village, which facilitate small-scale irrigation, or the demand for jatropha seeds from biofuel companies, we can see that this innovation is largely endogenous and grounded in existing plant resources and local practices, like the use of jatropha saplings as posts for bathrooms.
Perhaps the most surprising finding relates to the importance of the legal landscape created and maintained by traditional authorities. If the long-existing common grazing land designation had been revoked by the village head, the owners of (new) fields would not need to invest in fences.

By examining the landscape and the ecosystem services associated with a somewhat controversial tree species that is expanding, we are combining a strictly academic question with a question that has specific policy relevance. Thus we discuss the following two issues: (1) the extent to which our examination of the landscape is reflected in existing academic literature and (2) the consequences of our observations for the potential to scale up jatropha production within a sustainable and multifunctional agricultural landscape.

'African agricultural landscapes' is an often used and ill-defined term in the existing literature. In our effort at broad categorization, we are interested in studies that focus on the processes and patterns of fields, commons, and villages. We are not looking at the geography of forest transition or urbanization, or on the political ecology of, for example, contract farming, land reform, or land grabbing. We also acknowledge the existence of relevant contributions that defy categorization, e.g., because of their reflective nature (see Widgren 2012).

The older body of established literature on African agricultural landscapes, up to the 1970 s, was produced by western rural geographers, who focused on (often literally) mapping the structure of rural settlements and agrarian land-use patterns (e. g., Hunter 1967, Davies 1973, MacMaster 1975, Stevens and Lee 1979). This body of work is detailed but descriptive. It seems to have been largely discontinued after the 'cultural turn' in western geography.

A second body of work, published largely in the 1980s and 1990s, focused on understanding the landscape from the perspectives of local people, their histories, knowledge, and experiences (e.g., Mortimore 1989, Fairhead and Leach 1996). Challenging European views, which emerged in colonial times, that rural Africans were mismanaging their environment, destroying the forests, depleting their soils, and causing desertification, these authors produced finely observed counter narratives, which offered insights into quotidian agrarian practices, and the longterm and often resilient nature of strongly intertwined humanenvironment relationships. We have not found much work that combines the above two bodies of literature for a more forwardlooking purpose.

A third and much smaller body of literature is that of 'settlement ecology,' a more recent anthropological approach characterized by Kellett (2010:12) as "an outgrowth of location studies in geography." The term settlement ecology is used in studies that seek to understand the factors that drive agrarian settlements, drawing on anthropology, archaeology, geography, and ecology of the settlement itself and the surrounding areas, which sustained it. Mostly this research relates to long abandoned, non-European settlements in the Americas (e.g., Kellett 2010, Jones 2010). However the term settlement ecology is also used by Stone (1996) in a seminal book on Nigeria's contemporary Kofyar people and the recent socio-spatial history of their distinctive settlements and fields, shaped under processes of population growth, agricultural 
intensification, and micromigrations across an ecological gradient.

In short, we would argue that the scope of our study is relatively unique because there is very little recent literature that seeks to read living African agricultural landscapes to better address contemporary questions of agrarian change and the uptake of more sustainable farming practices. For a noteworthy exception, see Leach et al. (2012) who provide a settlement/landscape informed critique on the contemporary excitement in the carbon finance sector around biochar in soils. To take this kind of research to its full potential, renewed attention to African agricultural landscapes should build on the strengths of previous studies, combining the mapping skills of quantitative geographers and the anthropological approaches by post-colonial rural researchers, under a process-oriented, systems based and landscape scale analysis that is exemplified in Stone's settlement ecology.

\section{Scaling up scenarios}

In the introduction, we argued that there is a need to understand locally rooted tree planting and tree management practices as a prerequisite to the effective promotion and successful adoption of new agroforestry measures. In our case study area, the arable landscape, largely a maizescape, is almost devoid of trees, and jatropha hedges represent the most significant and widespread planting of new trees. The biofuel hype has exposed farmers to the idea of extensive planting of jatropha, and this provides us with an opportunity to examine the potential consequences of such 'scaling up' of tree planting practices. How far can it go and how does it affect the balance of ecosystem services provision?

Before we address this question, it is useful to reflect on the possible levels of scaling up. For illustrative purposes, we have developed some simple scenarios for scaling up jatropha hedge plantings per landscape unit:

- In the village: jatropha is planted around each household yard;

- In the grazing common: jatropha is planted along the main paths, which are visible on satellite images;

- On arable land: jatropha is planted along property (field) boundaries;

- And, in dambo wetlands: no hedge planting possible because it is too wet for jatropha.

Repeated measures on SPOT images of villages in the Eastern Province show that the average yard measures about $8 \mathrm{~m}$ in radius (see also Fig. 4). A full hedge around the yard would therefore be about $50 \mathrm{~m}$ long $(2 * 8 * \pi)$. If adjacent households share hedges, then that amount could be halved $(25 \mathrm{~m})$.

Planting jatropha along roads, which cut across the common grazing land means that hedges are easily accessible for seed collection and that labor intensive weeding needs to take place on only one side of the hedge. SPOT images on Google Earth show a network of roads and paths radiating out from the village, through the grazing common to the fields. For the Sikwenda village, we have measured a value of $80 \mathrm{~m}$ of road through common land, per household. Given that a road can have hedges on either side, this amounts to $160 \mathrm{~m}$ of hedges per household.

Fig. 4. Examples of woodland features in the agricultural landscape: single mango trees on arable land, live fence around the vegetable gardens in the dambo, and yard hedge in the village (same image as Fig. 2, zoomed in for greater detail).

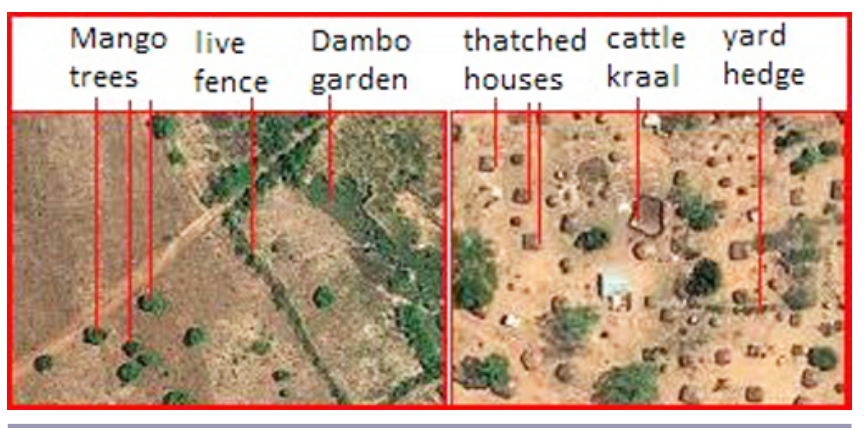

Our farmer survey (Kuntashula et al. 2014) revealed an average household had 3.2 ha under cultivation, plus some fallow land. If we assume that every household has one square field of 3 ha with two sides planted with their own hedges, this equates to 346 $\mathrm{m}$ of hedges $\left(2 \times \sqrt{30,000} \mathrm{~m}^{2}\right)$.

To make more sense of these scenarios, we can use two obvious benchmarks: (1) current production of jatropha seeds from existing bushes in the village and (2) national biodiesel demand. In 2011, the biofuel company D1 bought $2000 \mathrm{~kg}$ of jatropha seeds, which the villagers of Sikwenda had collected from existing bushes. This equates to about $20 \mathrm{~kg} /$ household. This means that planting jatropha along all yards, would double current jatropha production. Planting it along roads in the grazing common would yield 6 times more jatropha, and planting it as hedges around existing maize fields could yield 14 times more jatropha (Table 1). Zambia consumes about 730 million liters of diesel per year, which divided over 14 million inhabitants is 52 liters/person/year. We know that there is significant diversity in agricultural landscapes in Zambia, but if for the sake of argument we assume that that our case study represents the average agricultural landscape, then the landscape capacity for jatropha hedges, based on the above scenarios, across the whole of Zambia would amount to between $11.6 \%$ and $18.6 \%$ of the total national diesel consumption. This is much more than the existing government target of 5\% biodiesel. Diesel is relatively expensive in this land-locked country, which has no domestic oil resources (\$1.6/liter), so producing a diesel substitute would save the government a significant amount of foreign currency and redirect much of this money into the rural economy. Therefore, based on aggregate numbers, supporting jatropha biodiesel production sounds like an enticing proposition.

These are simply indicative figures, but they illustrate that a very significant scaling up of planting is theoretically possible without negative impacts on food production through the displacement of food crops. In terms of land coverage, the areas allocated to hedges in our scenarios remain modest. However given our findings in the field, it would require a profound and systemic 
Table 1. Potential yield scenarios for three different landscape units.

\begin{tabular}{lccc}
\hline \hline Landscape units & Hedge / household & Seed (assuming 0.8 kg/m ${ }^{\dagger}$ ) & Oil (manual vs. mechanized press) \\
\hline Arable land (maize fields) & $346 \mathrm{~m}$ & $276.8 \mathrm{~kg}$ & $55.4-88.61$ \\
Common grazing land & $160 \mathrm{~m}$ & $128 \mathrm{~kg}$ & $25.6-41.01$ \\
Village & $25 \mathrm{~m}$ & $20 \mathrm{~kg}$ & $4-6.41$ \\
Total & $531 \mathrm{~m}$ & $424.8 \mathrm{~kg}$ & $85-1361$ \\
\hline
\end{tabular}

${ }^{\dagger}$ Figure derived from a case study in Mali (Henning 2007, as quoted in Brittaine and Lutaladio 2010).

change in the agricultural system before farmers would invest labor in these hedges at that scale.

When they started their operations, biofuel companies in Zambia encouraged farmers to grow jatropha in the field. Later, in response to the global debate around food or biofuel, D1 encouraged the planting of jatropha hedges along the field margins of existing arable land. However, we observed that local hedge planting practices never took place on existing arable land. Farmers only planted hedges around new fields, which were being created in the grazing commons. A more grounded scenario for jatropha seed production in the type of agricultural landscape that we studied would have to be based on the rate of conversion of common grazing land to arable fields. We have not sought to quantify this figure, but we could expect it to be of a scale that is perhaps at best comparable to a hedge around the yard, i.e., only $5 \%$ of the indicative total seed production capacity in Table 1 . In short, our landscape-informed approach to the likely uptake of jatropha hedges showed a huge discrepancy between an adoption rate that mirrors farmer behavior and priorities, and any technical or top-down assessment of how many trees the landscape could absorb.

\section{Scaling up of hedge planting: consequences for ecosystem services}

What does it mean to a 'multifunctional' plant to be planted more widely and extensively? We would argue that the usual typology of ecosystem services works relatively well at the landscape level but is less satisfactory at a finer spatial level. It is important to start at the subplant level to identify what characteristics of the plant make it useful to people. Table 2 lists these for the locally embedded uses we have encountered. In the literature, there are many more potential uses being identified, but we have not observed these on the ground. For example, we didn't find any farmers who collected the leaves as fertilizer, and even after cutting down the encroaching jatropha bushes around their house, a Sikwenda family dismissed the idea of using the wood for the fire because "it burns too quickly," i.e., they preferred to use hardwood species. Some potential uses have disappeared over time. People in Sikwenda said their parents had used the seeds to provide lighting services, but they had stopped this. Government health workers had told one farmer that the fumes from the jatropha seeds are poisonous.

On the other hand, we saw some new uses too. We met an elderly farmer in the Central Province who was using jatropha as a biopesticide against stalk borers in maize, showing us the dead insects as evidence of success. Dozens of farmers in the Nyimba district were using jatropha for live fences around vegetable gardens by the home, planted so densely that it kept even the goats
Table 2. Observed traditional uses of Jatropha curcas: the services provided by key parts of a single tree.

\begin{tabular}{lll}
\hline \hline $\begin{array}{l}\text { Relevant parts of } \\
\text { the tree }\end{array}$ & Service provided & $\begin{array}{l}\text { Ecosystem services } \\
\text { (ES) category }\end{array}$ \\
\hline Flowers & "nice flowers" & $\begin{array}{l}\text { Aesthetic value } \\
\text { (cultural) }\end{array}$ \\
$\begin{array}{l}\text { Flowers for bees } \\
\text { Seed (small } \\
\text { amounts) }\end{array}$ & $\begin{array}{l}\text { "honey tastes bitter" } \\
\text { ("will make you vomit } \\
\text { in two directions") }\end{array}$ & $\begin{array}{l}\text { Biochemicals and } \\
\text { pharmaceuticals } \\
\text { (provisioning) }\end{array}$ \\
$\begin{array}{l}\text { Seed (large } \\
\text { amounts) }\end{array}$ & $\begin{array}{l}\text { Pressed to produce oil } \\
\text { for biodiesel, lighting, } \\
\text { soap }\end{array}$ & $\begin{array}{l}\text { (provisioning) } \\
\text { Saplings for }\end{array}$ \\
$\begin{array}{l}\text { Tall branches (tree } \\
\text { is coppiced) }\end{array}$ & $\begin{array}{l}\text { propagation, fence } \\
\text { posts for bathrooms } \\
\text { and live fences }\end{array}$ & $\begin{array}{l}\text { Building material } \\
\text { (provisioning) }\end{array}$ \\
Leaves (dense) & Wind break & $\begin{array}{l}\text { Climate regulation } \\
\text { (regulating) }\end{array}$ \\
$\begin{array}{l}\text { Leaves (dense, on a a } \\
\text { single stem tree) }\end{array}$ & Shade & $\begin{array}{l}\text { Climate regulation } \\
\text { (regulating) }\end{array}$ \\
\hline
\end{tabular}

and chickens out. This was clearly a new practice because traditionally vegetable gardens were only found in the dambo. These gardens next to the home were promoted by an NGO after water wells with hand pumps were installed in the village so that irrigation water was at hand. Farmers were encouraged to plant vegetables in these gardens, but many chose to plant traditional maize varieties at the very start of the rainy season. Irrigated for only a short time, and being more drought resistant than the hybrid maize, which farmers tended to grow on their main fields, the farmers' rationale for growing traditional maize in these novel gardens was to reduce food insecurity at a time when the main crop was still ripening in the field.

The above examples of different uses of jatropha point out the need to plant and manage individual trees differently to shape them in accordance with the service they are expected to provide, e.g., shade trees should not be coppiced and live fences are created by planting saplings very close together. The above, along with Table 2, also indicates the potential seasonality of the services provided, e.g., there is no need for stalk borer pesticide after the maize has been harvested, and the shade tree cannot provide shade in the dry season when it has lost all its leaves.

Table 3 displays the possible scaling up effects of particular uses, traditional and new, of Jatropha curcas trees. At the whole-tree level, it is important to examine how the plant is planted and managed, and how this is linked to the particular ecosystem 
Table 3. Uses of (whole) jatropha trees, and the key ecosystem services (ES) associated with these plants at the site and the landscape levels. (normal text is from field observations, text in italics is hypothetical/from the literature)

\begin{tabular}{|c|c|c|c|}
\hline Uses of jatropha trees & $\begin{array}{l}\text { ES rationale at the plant } \\
\text { and site levels }\end{array}$ & Synergies and substitutes & Landscape level ES \\
\hline Single tree in the yard & Shade & Other species also used & (Limited scaling up) \\
\hline Bathroom posts & $\begin{array}{l}\text { Fence post, cooling (shade), } \\
\text { privacy }\end{array}$ & Dead wood also used & (Limited scaling up) \\
\hline Yard hedge & $\begin{array}{l}\text { Privacy, wind break, source } \\
\text { of saplings }\end{array}$ & $\begin{array}{l}\text { Can encroach on the yard. } \\
\text { Other species also used }\end{array}$ & $\begin{array}{l}\text { Greening the yard; property } \\
\text { demarcation and enclosure of land } \\
\text { within settlements }\end{array}$ \\
\hline Live fence for garden & $\begin{array}{l}\text { Keeps chickens and goats } \\
\text { out }\end{array}$ & Dead wood also used & Concentrates grazing elsewhere \\
\hline Live fence around kraal & Shade for cows & $\begin{array}{l}\text { Complements a sturdy dead } \\
\text { wood fence }\end{array}$ & (Limited scaling up) \\
\hline $\begin{array}{l}\text { Abandoned/invasive } \\
\text { jatropha grove }\end{array}$ & (Limited use) & $\begin{array}{l}\text { Displaces grass. Harbors } \\
\text { wasps, snakes }\end{array}$ & $\begin{array}{l}\text { Affects village ecosystem, might affect } \\
\text { microclimate in the village }\end{array}$ \\
\hline Live hedge around field & (Novel) seed yield & $\begin{array}{l}\text { Might displace other crops a } \\
\text { little }\end{array}$ & $\begin{array}{l}\text { Increases habitat connectivity, } \\
\text { benefitting woodland edge species; } \\
\text { fixes property boundaries }\end{array}$ \\
\hline Plantation/crop & (Novel) seed yield & $\begin{array}{l}\text { Direct displacement of other } \\
\text { crops }\end{array}$ & $\begin{array}{l}\text { Protection against soil erosion (no } \\
\text { ploughing), impact on evapo- } \\
\text { transpiration... }\end{array}$ \\
\hline
\end{tabular}

services that it is designed to provide. At the site level, we need to examine what the plant has displaced, or might displace. Here we want to know what was on the site before the plant grew there, and what the impacts are of this type of land cover change in terms of ES availability and accessibility. At the landscape level we are particularly interested in the spatial arrangement, i.e. how does the shape and management of the plantation within the actual context of the surrounding landscape affect ES provision and distribution.

\section{CONCLUSIONS}

Agroforestry is widely promoted in Africa by organizations concerned with sustainable agriculture. There is much case-study evidence and many first-principle arguments to support the thesis that the planting and management of trees in an agricultural landscape can help to provide a whole range of different ecosystem services across the three major categories of provisioning, regulating, and cultural. But farming landscapes can be very diverse and there are many possible practices that farmers could adopt in relation to tree planting and management. There is a risk that by listing many potential ecosystem services, win-win situations are assumed to be generic, whereas real world trade-offs and conflicts are overlooked. Our local case study highlights several important and interlinked lessons.

First of all, the failed effort to turn jatropha into a cash crop showed us that the yard, the field, and the common grazing land are separate subsystems, and the transfer of plant management practices from one to the other did not run smoothly. It illustrated that farming should be seen as a nested system that (1) is spatially defined to include the village ecosystem as well as the arable fields and common grazings/forest land, and (2) is socially defined by units ranging from individuals to households to extended families and villages under traditional authority. Understanding how the dynamic relationships between land and labor play out in different parts of the agricultural landscape is a prerequisite for determining the limiting factors of production in different locations at different times of the day and year. In our case-study area, this 'reading the landscape' showed that for establishing jatropha on arable land, labor was the main limiting factor.

Second, we saw that some ecosystem services were far less scalable than others, e.g., medicinal use required a single tree for several villages; shade was hardly scalable beyond the yard; erosion control would logically require long lines of hedges along contour lines; and the logic of the biofuel market decried such high production levels that whole landscapes would have to be converted into jatropha hedges if not into jatropha fields. So although it is true that hedges are multifunctional, the synergies between the different ecosystem services, which a plant like jatropha can provide in any given landscape, are very much limited by this systemic mismatch in scale. That means that we should critically assess the marginal increase in individual ecosystem services as the scale of tree plantings increases. Given that different ecosystem services often have different beneficiaries, we must be alert to the risk that increased tree planting will benefit some groups to the relative (or even absolute) detriment of other sections in society.

Third, we must understand the property landscape in which tree planting takes place. It was the ownership of livestock that led to the village bylaw, which delineated common grazing land that provided the niche for jatropha from an ecological perspective, i.e., selective grazing favoring jatropha and a legal perspective, i.e., the onus on the field owner to protect the crop through fencing, respectively. Planted trees are usually privately owned and they are instruments for land enclosure. The absence of planted trees gives the traditional authorities, i.e., the chief or village head, the flexibility to reallocate land in response to differing needs within the community. Finally, trees can bring disbenefits, from harboring animals that can damage certain crops, to the use of water and 
nutrients and the creation of unwanted shade. Trees that are planted at the boundary of one property are likely to affect the neighbor, potentially creating local externalities and conflict.

Moreover, our effort to read the local agricultural landscape has allowed us to make different types of contributions. By revealing where and how processes of microenclosure and land conversion are taking place, our study provides new insights into the delicate interplay between land, labor, and capital during the process of agricultural intensification. Our focus on the emergence of new hedges in the agricultural landscape is also novel. There are many studies of hedges but these are mainly historical, cultural, or ecological in nature and relate to long established or disappearing hedges. By deepening our understanding of what farmers do with different trees in different parts of the landscape, we can engage critically with questions of adoption and diffusion of agroforestry and the impacts that the scaling up of new crop systems can have on different ecosystem services. And finally by choosing jatropha as our case study plant, we were able to ground-truth some of the general claims made by proponents and opponents of biofuels. Embracing settlement ecology as a forward-looking concept, we argue that a better understanding of the living agricultural landscape and the processes of its evolution is crucial for assessing the plausible impacts of any external drivers for change.

Responses to this article can be read online at: http://www.ecologyandsociety.org/issues/responses. php/6437

\section{Acknowledgments:}

Funding for this study was generously provided by the UK research councils and DFID under the Ecosystem Services for Poverty Alleviation (ESPA) programme; ref NE/I003819/1. We are hugely indebted to the many Zambian farmers who welcomed us to their villages and homesteads and shared their opinions, memories, wisdom, and humor with us.

\section{LITERATURE CITED}

Achten, W. M. J., E. Mathijs, L. Verchot, V. P. Singh, R. Aerts, and B. Muys. 2007. Jatropha biodiesel fueling sustainability? Biofuels, Bioproducts and Biorefining 1(4):283-291.

Ariza-Montobbio, P., S. Lele, G. Kallis, and J. Martinez-Alier. 2010. The political ecology of Jatropha curcas plantations for biodiesel in Tamil Nadu, India. Journal of Peasant Studies 37 (4):875-897. http://dx.doi.org/10.1080/03066150.2010.512462

Boerstler, F. 2010. The potential for the production of biodiesel for lighting and cooking using Jatropha (Jatropha curcas $L$. Euphorbiaceae) by small scale farmers on the Kenyan coast. Dissertation. Aachen University, Aachen, Germany.

Boserup, E. 1965. The conditions of agricultural growth: the economics of agrarian change under population pressure. Routledge, London, UK.

Brittaine, R., and N. Lutaladio. 2010. Jatropha: a small holder energy crop. The potential for pro-poor development. Integrated Crop Management Volume 8. Food and Agriculture Organization of the United Nations, Rome, Italy. [online] URL: http://www. fao.org/docrep/012/i1219e/i1219e00.htm

Budowski, G., and R. O. Russo. 1993. Live fence posts in Costa Rica: a compilation of the farmer's beliefs and technologies. Journal of Sustainable Agriculture 3:65-87. http://dx.doi. org/10.1300/J064v03n02 07

Burel, F. 1996. Hedgerows and their role in agricultural landscapes. Critical Reviews in Plant Sciences 15(2):169-190. http://dx.doi.org/10.1080/07352689.1996.10393185

Choudhury, P. R., P. Rai, U. S. Patnaik, and R. Sitaram. 2005. Live fencing practices in the tribal dominated eastern ghats of India. Agroforestry Systems 63:111-123. http://dx.doi.org/10.1007/ $\underline{\text { s10457-004-1123-8 }}$

Davies, H. J. R. 1973. Tropical Africa: an atlas for rural development. University of Wales Press, Cardiff, UK.

Dyer, J. C., L. C. Stringer, and A. J. Dougill. 2012. Jatropha curcas: sowing local seeds of success in Malawi? In response to Achten et al. (2010) Journal of Arid Environments 79:107-110. http://dx. doi.org/10.1016/j.jaridenv.2011.12.004

Fairhead, J., and M. Leach. 1996. Misreading the African landscape. Society and ecology in a forest-savanna mosaic. Cambridge University Press, Cambridge, UK. http://dx.doi. org/10.1017/CBO9781139164023

Franzel S., D. Phiri, and F. R. Kwesiga. 2002. Assessing the adoption potential of improved fallows in eastern Zambia. Pages 37-64 in S. Franzel and S. J. Scherr, editors. Trees on the farm: assessing the adoption potential of agroforestry in Africa 2002. CAB International, Wallington, UK. http://dx.doi. org/10.1079/9780851995618.0037

Fukamachi, K., Y. Miki, H. Oku, and I. Miyoshi. 2011. The biocultural link: isolated trees and hedges in Satoyama landscapes indicate a strong connection between biodiversity and local cultural features. Landscape and Ecological Engineering 7 (2):195-206. http://dx.doi.org/10.1007/s11355-011-0164-1

Henning, R. 1996. Combating desertification: the jatropha project of Mali, West Africa. Aridlands Newsletter No. 40. [online] URL: http://ag.arizona.edu/oals/ALN/aln40/jatropha.html

Henning, R. K. 2007. Fuel production improves food production: the jatropha project in Mali. Pages in G. M. Gübitz, M. Mittelbach, and M. Trabi, editors. Biofuels and industrial products from Jatropha curcas. Developed from the February 23-27 1997 symposium “Jatropha 97”, Managua, Nicaragua. Dbv-Verlag für die Technische Universität Graz, Graz, Austria.

Hinsley, S. A., and P. E. Bellamy. 2000. The influence of hedge structure, management and landscape context on the value of hedgerows to birds: a review. Journal of Environmental Management 60:33-49. http://dx.doi.org/10.1006/jema.2000.0360

Holland, J., and L. Fahrig. 2000. Effect of woody borders on insect density and diversity in crop fields: a landscape-scale analysis. Agriculture, Ecosystems and Environment 78:115-122. http://dx.doi.org/10.1016/S0167-8809(99)00123-1

Hunsberger, C. 2010. The politics of Jatropha-based biofuels in Kenya: convergence and divergence among NGOs, donors, 
government officials and farmers. Journal of Peasant Studies 37 (4):939-962. http://dx.doi.org/10.1080/03066150.2010.512465

Hunter, J. 1967. The social roots of dispersed settlements in Northern Ghana. Annals of the Association of American Geographers 57:339-349. http://dx.doi.org/10.1111/j.1467-8306.1967. $\underline{\mathrm{tb} 00607 . \mathrm{x}}$

Jones, E. E. 2010. An analysis of factors influencing sixteenth and seventeenth century Haudenosaunee (Iroquois) settlement locations. Journal of Anthropological Archaeology 29(1): 1-14. http://dx.doi.org/10.1016/j.jaa.2009.09.002

Jongschaap, R. E. E., W. J. Corré, P. S. Bindraban, and W. A. Brandenburg. 2007. Claims and facts on Jatropha curcas L.: global Jatropha curcas evaluation, breeding and propagation programme. Report 158. Plant Research International, Wageningen UR, Wageningen, the Netherlands. [online] URL: http://edepot.wur. $\underline{\mathrm{n} 1 / 41683}$

Kabwe, G. 2010. Uptake of agroforestry technologies among smallholder farmers in Zambia. Dissertation. Lincoln University, Lincoln, New Zealand. [online] URL: http://researcharchive. lincoln.ac.nz/handle/10182/2970

Kellett, L. 2010. Chanka settlement ecology: hilltop sites, land use and warfare in late prehispanic Andahuaylas, Peru. Dissertation. University of New Mexico, Albuquerque, New Mexico, USA. [online] URL: http://repository.unm.edu/handle/1928/10881

Kelso, A., and M. Jacobson. 2011. Community assessment of agroforestry opportunities in GaMothiba, South Africa. Agroforestry Systems 83:267-278. http://dx.doi.org/10.1007/ $\underline{\text { s10457-011-9384-5 }}$

Kuntashula, E., D. van der Horst, and S. Vermeylen. 2014. A propoor biofuel? Household wealth and farmer participation in Jatropha curcas seed production and exchange in Eastern Zambia. Biomass and Bioenergy 63:187-197. http://dx.doi.org/10.1016/j. biombioe.2014.01.051

Leach, M., J. Fairhead, and J. Frazer. 2012. Green grabs and biochar: revaluing African soils and farming in the new carbon economy. Journal of Peasant Studies 39(2):285-307. http://dx.doi. org/10.1080/03066150.2012.658042

Levasseur, V., M. Djimdé, and A. Olivier. 2004. Live fences in Ségou, Mali: an evaluation by their early users. Agroforestry Systems 60:131-136. http://dx.doi.org/10.1023/B:

$\underline{\text { AGFO.0000013268.44627.2f }}$

MacMaster, D. 1975. Geography of rural settlements. Pages 121-147 in J. I. Clarke, editor. An advanced geography of Africa. Hulton, Amersham, UK.

Mortimore, M. 1989. Adapting to drought: farmers, famines and desertification in West Africa. Cambridge University Press, Cambridge, UK. http://dx.doi.org/10.1017/CBO9780511720772

Mponela, P., C. B. L. Jumbe, and W. F. Mwase. 2011. Determinants and extent of land allocation for Jatropha curcas L. cultivation among smallholder farmers in Malawi. Biomass and Bioenergy 35:2499-2505. http://dx.doi.org/10.1016/j.

biombioe.2011.01.038
Openshaw, K. 2000. A review of Jatropha curcas: an oil plant of unfulfilled promise. Biomass and Bioenergy 19:1-15. http://dx. doi. org/10.1016/S0961-9534(00)00019-2

Oreszczyn, S., and A. Lane. 2000. The meaning of hedgerows in the English landscape: different stakeholder perspectives and the implications for future hedge management. Journal of Environmental Management. 60:101-118. http://dx.doi.org/10.1006/ jema.2000.0365

Stevens, R., and Y. Lee. 1979. A spatial analysis of agricultural intensity in a Basotho village of Southern Africa. Professional Geographer 31(2):177-183. http://dx.doi.org/10.1111/ j.0033-0124.1979.00177.x

Stone, G. D. 1994. Agricultural intensification and perimetrics: ethnoarcheological evidence from Nigeria. Current Anthropology 35(3):317-325. http://dx.doi.org/10.1086/204283

Stone, G. D. 1996. Settlement ecology: the social and spatial organization of Kofyar agriculture. University of Arizona Press, Tucson, Arizona.

Usieta, H. O., S. A. Manu, and U. Ottosson. 2013. Farmland conservation in West Africa: how do hedgerow characteristics affect bird species richness? Bird Study 60(1):102-110. http://dx. doi.org/10.1080/00063657.2012.758226

van der Horst, D., T. Chibwe, and S. Vermeylen. 2013. Soap security: African home economics in the aftermath of the jatropha biofuel hype. Solutions 3(6).

van der Horst, D., and S. Vermeylen. 2011. Spatial scale and social impacts of biofuel production. Biomass and Bioenergy 35:2435-2443. http://dx.doi.org/10.1016/j.biombioe.2010.11.029

Widgren, M. 2012. Resilience thinking versus political ecology: understanding the dynamics of small-scale, labour intensive farming landscapes. Pages 95-110 in T. Plieninger and C. Bieling C., editors. Resilience and the cultural landscape. Understanding and managing change in human-shaped environments. University of Cambridge Press, Cambridge, UK. http://dx.doi.org/10.1017/ CBO9781139107778.008

Williams, V. J. 2011. A case study of desertification in Haiti. Journal of Sustainable Development 4(3):20-31. http://dx.doi. org/10.5539/jsd.v4n3p20

Zahawi, R. A. 2005. Establishment and growth of living fence species: an overlooked tool for the restoration of degraded areas in the tropics. Restoration Ecology 13(1):92-102. http://dx.doi. org/10.1111/j.1526-100X.2005.00011.X 